\title{
Innovation of Learning Social with LSLC to Develop Students' HOTS Ability at Junior High School 14 Mataram
}

\author{
Hairil Wadi* \\ Sociology Education \\ University of Mataram \\ Mataram, Indonesia \\ wadifkipunram@gmail.com \\ Ni Made Novi Suryanti \\ Sociology Education \\ University of Mataram \\ Mataram, Indonesia \\ novifkip@unram.ac.id
}

\author{
S Sukardi \\ Sociology Education \\ University of Mataram \\ Mataram, Indonesia \\ sukardi@unram.ac.id \\ Nurlaily Handayani \\ Sociology Education \\ University of Mataram \\ Mataram, Indonesia \\ handayani@unram.ac.id
}

\begin{abstract}
This study aimed to determine the innovation of social studies learning by teachers through the Lesson Study For Learning Community (LSLC), which can develop higher-order thinking skills (HOTS) of students at Junior High School 14 Mataram. The research method uses descriptive qualitative by collecting data through observation and documentation techniques. While data analysis techniques using the Miles \& Huberman model include data reduction, data presentation, and concluding. The results of the research show that there is a social science learning innovation by a team of social studies teachers following the stages of the Lesson Study For Learning Community (LSLC) which can develop Higher Order Thinking Skills (HOTS) of students at Junior High School 14 Mataram including 1) Social studies learning innovation in the planning stage, namely the team Social studies teachers have produced the preparation of Chapter design by selecting Basic Competencies with Higher Order Thinking Skills (HOTS) and mapping the essential material for class VIII, compiling lesson designs by compiling steps for social studies learning activities containing Higher Order Thinking Skills (HOTS) Class VIII, 2) Social studies learning innovation in the Implementation stage (Do), namely the model teacher has applied the social studies learning innovation with the Coopearative learning and Discovery learning models that can develop students' Higher Order Thinking Skills (HOTS) in the form of problem solving, decision making, critical thinking, arguing and collaborating, moderate the observer team observed sis activities wa when learning takes place by standing, taking pictures without light; 3) Social studies learning innovation in the reflection stage (See), namely the social studies teacher team reflecting on the strengths and weaknesses of social studies learning after developing students' Higher Order Thinking Skill (HOT) abilities carried out by model teachers. So there needs to be an optimal effort from the social studies teacher team to stimulate students' HOTS abilities in social studies learning, leading to the ability to analyze, evaluate, and create through the application of creative and innovative learning models.
\end{abstract}

Keywords—lesson study, high order thinking, social.

\section{INTRODUCTION}

Government Regulation of the Republic of Indonesia Number 19 of 2017 explains that teachers are professional educators who can create a quality learning process [1] through the development of innovative learning according to the demands of the 21st century oriented towards students' Higher Order Thinking Skill (HOTS) abilities. Including junior high school social studies subjects taught by social studies teachers. However, the reality is still not optimal in its implementation. The proof is that conventional social studies teaching is still inherent in social studies teachers [2], which emphasizes the authoritarianism of teachers in learning and there is no willingness at all to change themselves. As a result, students in social studies learning are less directly involved in learning activities that explore students' higher-order thinking skills or Higher Order Level Skills (HOTS). Whereas HigherOrder Level Skill (HOTS) according to Sutaryanto's Research [3] can support students' high-level thinking skills in the aspects of analyzing, evaluating, and creating. Indeed, so far, student learning activities are only more dominant in listening, taking notes on material explanations from the teacher and then given assignments without any feedback.

The emergence of these problems requires a solution that can change the teaching patterns of social studies teachers through an innovative learning strategy oriented towards students' higher order thinking skills or Higher Order Thinking Skills (HOTS). Why innovation in social studies learning ?. Because social studies learning innovation tries to create or implement something that is able to answer a problem [4] and something new or an old product that is not really new but is able to facilitate students in higher-order thinking skills activities. Zohar in Sutrisno [5] stated that every student needs to use HOTS. Then Levonen \& Meisalo (Sutrisno, 2011) explained that students' HOTS is directed at the ability to think critically, creatively, solve problems, give arguments, ask questions, and make conclusions. Kurniawan's research [6] The use of HOTS-oriented recovery learning innovations can improve student learning outcomes in building materials. Research by Marhadi, et al [7] found that the higher order thinking skills (HOTS) of students who learn with the cooperative model innovation have a higher increase than those who learn conventionally in school-based management courses. Now based on this rationale, the social studies learning design innovation that can develop higher 
order thinking skills / Higher Order Thingking Skills is important for students to involve the social studies teacher team community through the Lesson Study For Learning Community (LSLC) pattern which includes the planning stages (Plan), the implementation stages ( DO) and the reflection stage (See).

Lesson Study For Learning Community (LSLC) is an activity to build a learning community between teachers to develop the quality of learning. Lesson study is a model of teaching professional development through collaborative and sustainable learning based on the principles of collaboration and mutual learning to build a learning community [8]. Lesson study is an effort to improve the learning process and outcomes which is carried out collaboratively and sustainably by a group of teachers [9]. Such as the collaboration carried out by social studies teachers at Junior High School 14 Mataram. Based on this description, the problem of how to innovate social studies learning HOT can be formulated through the Lesson Study For Learning Community (LSLC) at Junior High School 14 Mataram. Meanwhile, the purpose of this study was to determine the innovation of social studies learning through the collaboration of social studies teachers' Lesson Study for Learning Community (LSLC) which can develop Higher Order Thinking Skills (HOTS) of students.

\section{METHOD}

This study used a qualitative approach with descriptive methods by collecting data through observations of teacher and student activities during planning (Plan), implementation (Do), and reflection (See) of social studies learning which can develop students' Higher Order Thinking Skill (HOTS) ability activities in Junior High School 14. Mataram. Research location at Junior High School 14 Mataram which is located at Jalan Brawijaya No. 23 Cakaranegara, Mataram City. The subjects of this study were 5 social studies teachers including Toh teachers, Wid teachers, Abd teachers, Hud teachers, and Arba teachers, while the subjects of students were class VIII B totaling 28 people in the even semester of the 2019/2020 school year. Collecting data by observation and documentation using observation sheets and documents including chapter design implementation sheets, lesson design by social studies teachers, implementation of learning activities by model teachers and Higher Order Thinking Skill (HOTS) oriented student activities. The data obtained were analyzed using the qualitative model of Miles and Huberman including data reduction, data presentation, and conclusion drawing.

\section{RESULTS AND DISCUSSION}

Research data on the HOTS social studies learning innovation through the Lesson Study For Learning Community are as follows.

TABLE I. HOTS SOCIAL STUDIES LEARNING INNOVATION PLANNING STAGE

\begin{tabular}{|c|c|c|c|}
\hline NO & PLANNING STAGE & INNOVATION & HIGH ORDER THINKING \\
\hline 1 & $\begin{array}{l}\text { The teacher compiles the chapter design } \\
\text { (material mapping) for grade eightth }\end{array}$ & $\begin{array}{l}\text { Planning for creative social studies learning } \\
\text { through determining the basic competencies of } \\
\text { HOT class VIII and mapping essential materials }\end{array}$ & \\
\hline 2 & Lesson design development & $\begin{array}{l}\text { Planning for creative social studies learning by } \\
\text { making a table consisting of } 3 \text { columns of } \\
\text { Introduction, Core (sharing task jumping task) } \\
\text { and closing } \\
\text { The planning of social studies learning } \\
\text { objectives activates through the determination } \\
\text { of the cooperative method strategy and } \\
\text { discovery learning }\end{array}$ & $\begin{array}{l}\text { Think creatively } \\
\text { Why does Indonesia's economy } \\
\text { often lose in maritime-based economic } \\
\text { competitions? } \\
\text { How to develop Indonesia's maritime } \\
\text { economy? } \\
\text { High order thinking } \\
\text { Through the cooperative model and } \\
\text { discovery learning, students are } \\
\text { expected to be able to analyze and } \\
\text { present the results of the analysis of the } \\
\text { maritime economic model properly. }\end{array}$ \\
\hline
\end{tabular}

TABLE II. SOCIAL STUDIES LEARNING INNOVATION REFLECTION STAGE

\begin{tabular}{|c|c|c|c|}
\hline \multirow[t]{4}{*}{ Students } & $\begin{array}{l}\text { Implementation } \\
\text { Innovation }\end{array}$ & Activity & High Order Thinking \\
\hline & Active and Creative & $\begin{array}{l}\text { Identify and answer questions } \\
\text { Not staying in one place } \\
\text { Write and report on group work } \\
\text { Express opinions } \\
\text { Reflect and conclude }\end{array}$ & $\begin{array}{l}\text { Critical thinking } \\
\text { Creative thinking } \\
\text { Problem-solving } \\
\text { Decision Making }\end{array}$ \\
\hline & Effectively & $\begin{array}{l}\text { Working on worksheets in groups } \\
\text { Take advantage of the completeness of learning } \\
\text { tools }\end{array}$ & $\begin{array}{l}\text { Collaborate } \\
\text { Make decisions } \\
\text { Creative thinking }\end{array}$ \\
\hline & Great fun & Sing while learning & \\
\hline $\begin{array}{l}\text { Model Teacher opens the } \\
\text { class } \\
\text { The observer team } \\
\text { observes the learning } \\
\text { process }\end{array}$ & $\begin{array}{l}\text { Active } \\
\text { Creative } \\
\text { Effective } \\
\text { Fun }\end{array}$ & $\begin{array}{l}\text { Teaching with a scientific approach to the } \\
\text { Cooperative model and Discovery learning } \\
\text { Facilitating students through worksheets and } \\
\text { LCD, colorful quarto paper, manila paper, } \\
\text { scissors, markers and videos, student books, } \\
\text { articles }\end{array}$ & $\begin{array}{l}\text { Teacher teaching model oriented } \\
\text { to student abilities } \\
\text { Creative thinking } \\
\text { Collaborating } \\
\text { Problem Solving } \\
\text { Decision Making, } \\
\text { Critical thinking }\end{array}$ \\
\hline
\end{tabular}


TABLE III. SOCIAL STUDIES LEARNING INNOVATION REFLECTION STAGE

\begin{tabular}{|c|c|c|c|}
\hline Reflection (See) & Reflection Stage Innovation & Activity & High Order Thinking \\
\hline Teacher Team & Collaborate to reflect on learning & $\begin{array}{l}\text { From the teacher delivers the target } \\
\text { The observer team convey critics and } \\
\text { suggestions, during the lesson }\end{array}$ & $\begin{array}{l}\text { The team highlights } \\
\text { students' ability } \\
\text { problems, make decisions } \\
\text { and collaborate. }\end{array}$ \\
\hline
\end{tabular}

Research on social studies learning innovation by social studies teachers through the Lesson Study For Learning Community (LSLC) to develop Higher Order Thinking Skills for students in class VIII B Junior High School 14 Mataram was carried out in three stages, namely innovation in the planning stage (Plan), innovation in the implementation stage (Do), and innovation in the reflection stage (See).

Innovation In the planning stage (Plan), the Chapter design and lesson design of IPS are compiled. The chapter design has succeeded in the mapping (Mapping) essential social studies materials for class VIII B on Basic competence 3.3 (C4). , in Indonesia and ASEAN countries, 3.4 (C4). Presenting the results of an analysis of the advantages and limitations of space in supply and demand, technology, and its effects on the interaction between spaces for economic, social, cultural activities in Indonesia and ASEAN countries. Based on these competencies, the main topic is determined "Indonesian Maritime" with sub-topics including Indonesian Maritime, Indonesian maritime economic potential, Condition of the basic concept of maritime economy, Strategy, and Indonesian maritime economy policy.

The chapter design of the material mapping is designed using a circle format starting from the middle circle for large topics then covering small circles containing related subtopics. Until it comes to the determination of one sub-topic that is determined for one meeting, namely "Indonesia's maritime conditions". The Ministry of Education and Culture [9] explained that compiling the Chapter design format depends on the model that the teacher wants. This means that the learning innovation chapter design that has been compiled by the social studies teacher in the form of material mapping has led to creative innovation. Until the mapping of the material has been determined, there is a plan to design the learning for only one meeting.

Based on the chapter design planning that has been compiled for one meeting, it is continued to compile an Innovative IPS Lesson design with Higher Order Thinking Skill (HOTS) orientation. The Ministry of Education and Culture [10] states that lesson designs are compiled by social studies teachers to think about how students learn from start to finish to achieve their goals. The Social Science Innovation in Lesson design for one sub-material meeting "Model of strengthening the maritime economy, by making a table consisting of 3 columns where there is an introduction column, a core activity column, a closing. Technically, between the three columns, draw a line with colored markers starting from the top right corner to the bottom left corner using the left hand. In the upper right corner contains teacher assistance for activities carried out by students (Apersepsi, sharing tasks, jumping tasks). Meanwhile, those below the prediction line help teacher-student activities. In this lesson design, a learning approach is also determined, namely the SCL Cooperative method, and Discovery learning, the use of video media and PowerPoint, as well as determining the learning objectives using operational verbs to analyze. So the innovation of social studies learning planning. Lesson design designed by a team of social studies teachers leads to activation, creativity, effectiveness, and fun by developing Higher order thinking skills. Skills to think creatively.

Furthermore, at the implementation stage (DO), social studies innovation was implemented by a model teacher named Guru Wid accompanied by a team of 4 observers, namely Toh teacher, Hud teacher, Abd teacher and Arba teacher. During the learning process, there are a variety of activities directed by the model teacher by facilitating students who are oriented High order thinking skills including identifying and answering questions (students solving problems), students not staying in one place to write and reporting group work through student worksheets (students collaborate), use learning resources (creative thinking), students express opinions (think critically), reflect and conclude (make decisions). The Ministry of Education and Culture [10] explained that during the implementation (DO) there were various kinds of activities implemented by model teachers that led to activating innovation, namely facilitating students during learning activities using cooperative learning and discovery learning strategies, creative innovation using methods that varied in proposing challenging material, creating a variety of simple learning tools, managing classes, proposing challenging material, presenting material systematically, effective innovation (preparing worksheets, mastering material, using media) fun through singing activities, giving praise and appreciation to students from activities that's been done.

In the reflection stage (See) the social studies teacher team collaboratively provides input, direction, advantages and disadvantages of the learning that has been carried out by the model teacher. The Ministry of Education and Culture [10] stated that during the reflection the model teacher and observer conveyed the impression, the lessons learned and their findings, the observer did not criticize the way the teacher taught but provided input. From the reflection made by the teacher, the Social Science learning innovation model has used the cooperative learning model innovation and Discovery learning which develops students' higher thinking skills even though it is still not optimal. Meanwhile, the observer said that basically, students were able to solve problems, make decisions and collaborate in group conditions, even though it was still not optimal.

Thus that social studies learning innovation through Lesson Study For Learning The Community (LSLC) to develop students' Higher Order Thinking Skills at junior high school 14 Mataram has been carried out by teachers in optimal collaboration, although there are still shortages, but social studies teachers have shown professionalism. Saito (11) states that effective professional learning is a long-term commitment and is best implemented in a school community that promotes learning for all through LSLC which emphasizes the practice and belief of learning to advance. This means that the social studies teacher team does not stop trying to build their 
professionalism by synergizing or collaborating to innovate learning through learning approaches or strategies, learning media and learning resources that can potentially be utilized by students who are oriented towards higher order thinking skills / Higher Order Thinking Skills ( HOTS).

\section{CONCLUSION}

The Community (LSLC) to develop students' Higher Order Thinking Skills at Junior High School 14 Mataram has been carried out by teachers in optimal collaboration, although there are still shortages, social studies teachers have shown professionalism. Saito (2015) states that effective professional learning is a long-term commitment and is best implemented in a school community that promotes learning for all through LSLC which emphasizes the practice and belief of learning to advance. This means that the social studies teacher team does not stop trying to build their professionalism by synergizing or collaborating to innovate learning through learning approaches or strategies, learning media, and learning resources that can potentially be utilized by students who are oriented towards higher-order thinking skills / Higher Order Thinking Skills (HOTS).

\section{REFERENCES}

[1] Peraturan Menteri Pendidikan Nasional Republik Indonesia No.22 Tahun 2006 tentang Standar Isi Satuan Pendidikan Dasar dan Menengah.

[2] Wadi, et al., Lesson Study Penerapan CL Pendekatan Saintifik sebagai Upaya Meningkatkan Kemandirian dan Tanggung Jawab Siswa dalam Pembelajaran IPS Kelas VII SMP 1 Narmada. Laporan Penelitian PNBP FKIP University of Mataram, 2017.

[3] S. Sutaryanto, Analisis Penerapan Perangkat Pembelajaran Pada Pembelajaran IPS terhadap HOTS di SD Negeri 9 Purwodadi. Indonesia Jurnal Of Primary Education, vol. 4, no. 2, 2020.

[4] W. Sanjaya, Kurikulum dan pembelajaran (Teoritik dan Praktik kurikulum KTSP) Jakarta. Prenada Media Group, 2008.
[5] S. Sutrisno, Pengantar Pembelajaran Inovatif Berbasis Teknologi dan Komunikasi.Gaung Persada Press Jakarta, 2011.

[6] Kurniawan, "Penggunaan Model Discovery Learning Berorientasi HOTS Sebagai Upaya Meningkatkan Hasil Belajar Siswa. Theroems (The Original Research Of Matematics), vol 5, no. 1, 2020.

[7] M. Marhadi, H. Hendri, E. Erisnawati, "Peningkatan kemampuan berpikir Tingkat Tinggi ?HingherOrder Thinking Skill (HOTS) Mahasiswa PGSD FKIPUR. Pedagogik Jurnal Pendidikan Guru SD,", vol. 6 , no. $1,2018$.

[8] Hendayana et al., Lesson Study Suatu Strategi Untuk Meningkatakan Keprofesionalan Pendidik (Pengalaman IMSTEP-JICA). Bandung: UPI Press, 2007.

[9] A. Sudrajat, Lesson Study untuk Meningkatkkan Proses dan Hasil Belajar, 2019.

[10] Kemendikbud Direktorat Pendidikan Dasar dan Menengah Direktorat Pendidikan Sekolah Menengah Pertam. LSLC Pendampingan Sekolah Bermutu Berbasis Zonasi.Power Point Teks (PPT), 2019

[11] Saito, et al, Lesson Study For Learning Comunity a guide sustainable School Reform. Rouledge Taylor \&Francis Group London and New York, 2015. 